\title{
Aspects Regarding the Evaluation of the Microbiological Status of the Minced Meat Products From a Processing Unit
}

\author{
Adrian-Anton SĂLĂGIAN FLOREA ${ }^{1,2)}$, Marian MIHAIU ${ }^{1)}$ and Ioan PAȘCA ${ }^{1)}$ \\ 1)University of Agricultural Sciences and Veterinary Medicine, Faculty Of Veterinary Medicine, 3-5 \\ Manastur Street, 400372, Cluj-Napoca, Romania; \\ ${ }^{2)}$ Naposigal Quality S.R.L., 15 Viilor Street, 400347, Cluj-Napoca, Romania; \\ Corresponding author: asalagian@gmail.com \\ Bulletin UASVM Veterinary Medicine 72(1) / 2015, \\ Print ISSN 1843-5270; Electronic ISSN 1843-5378 \\ DOI:10.15835/buasvmcn-vm: 10495
}

\begin{abstract}
Minced meat and processed meat are raw products that are very susceptible to all microbiological factors to which they are exposed. In this study, 108 samples were analyzed during two years. The results have revealed the contamination following the human factor (1 case of Salmonella contamination at processed meat), respectivelly the high bacteria load in minced meat revealed by the Total Germ Count (TGC) and Escherichia coli values. These results were due to the semi-automatic packaging process (samples 1 - 42) and their significant decrease after the introduction of an automatic packaging system (samples 43-58). The conclusion of our study was that the packaging technology which limits the human contact and the environment surfaces contact ensures a safer product for the consumer.
\end{abstract}

Keywords: Escherichia coli, minced meat, hygiene, Salmonella spp, TGC.

\section{INTRODUCTION}

Due to its particular processing technology, the minced meat is susceptible to a high microbiological contamination. The most frequent ways to keep under control the technological process are the inner meat temperature (maximum $7^{\circ} \mathrm{C}$ ), and the environment temperatures $\left(\max .12^{\circ} \mathrm{C}\right.$ ) (Mihaiu et al. 2010).

In this study we have included also the products obtained from this meat and also the auxiliary substances used (additives, condiments).

\section{AIMS AND OBJECTIVES}

The research aims are assessment of the pathogenic bacteria prevalence in minced meat and minced meat products, evaluation of the biological hazards during the processing stages of minced meat and evaluation of the risk level for public health pose by these types of products.

\section{MATERIALS AND METHODS}

The microbiology testing discussed was conducted at a meat processing facility in Cluj County at a third-party lab certified by the Romanian Accreditation Association-RENAR. The products were tested for Escherichia coli using the Tempo method, TPC using the Tempo method, and Salmonella spp. according to the SR EN ISO 6579:2003/AC:2006 Microbiology of food and animal feeding stuffs - Horizontal method for the detection of Salmonella spp. For each parameter 5 samples were taken from the ground meat.

\section{RESULTS AND DISCUSSION}

The results used in the study came from microbiology tests for the specified parameters performed on samples collected for two years (2012-2013). There positive samples, especially from the semi-automated packaging process, 
The microbiological examination of the minced meat (58 samples)

\begin{tabular}{cccc}
\hline Analyzed parameter & $\begin{array}{c}\text { Total no. of } \\
\text { samples }\end{array}$ & $\begin{array}{c}\text { Total no. of } \\
\text { batches }\end{array}$ & Maximum accepted limit \\
\hline Salmonella & 54 & 270 & absent $/ 25 \mathrm{~g}$ \\
\hline Escherichia coli & 33 & 165 & max. 2 batches with values in between 50 and $500 \mathrm{ufc} / \mathrm{g}$ \\
\hline TGC & 27 & 135 & max. 2 batches with values in between $5 \times 10^{5}$ and $5 \times 10^{6} \mathrm{ufc} / \mathrm{g}$ \\
\hline
\end{tabular}

The microbiological examination of the minced meat processed products (50 samples)

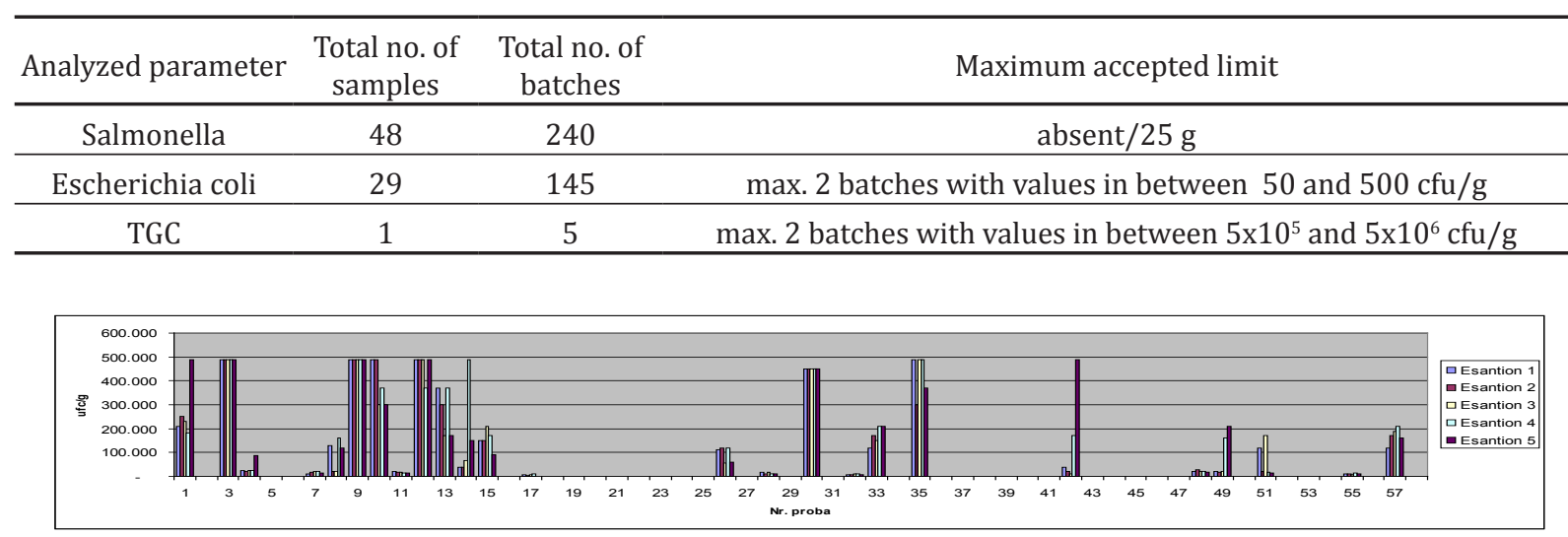

Fig. 1. TGC values in minced meat.

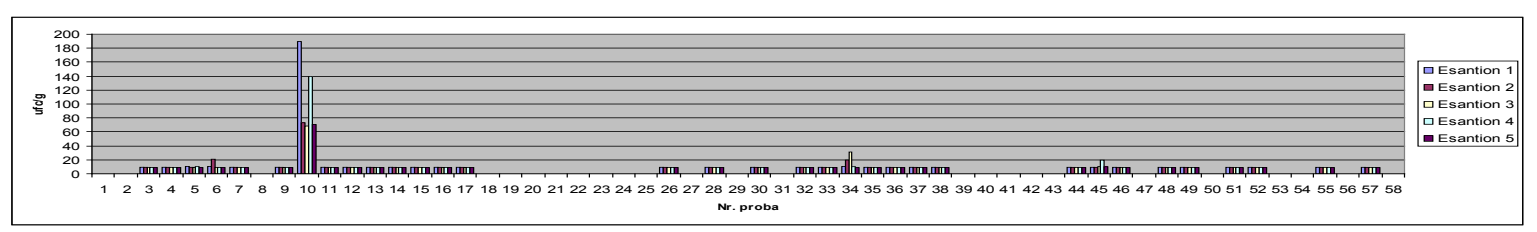

Fig. 2. Escherichia coli values in minced meat.

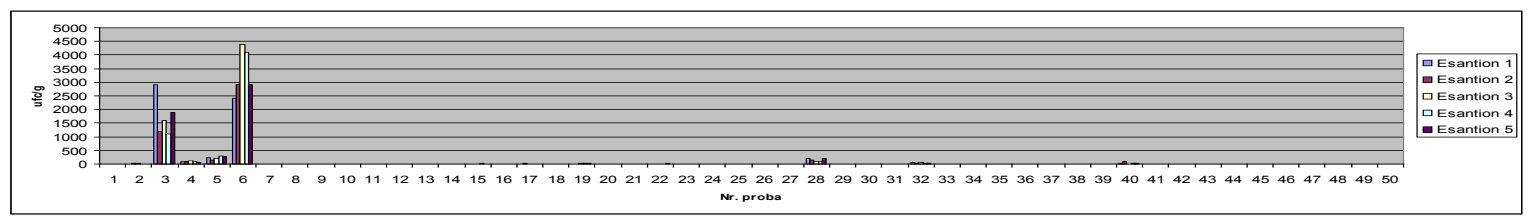

Fig. 3. Escherichia coli values in minced meat processed products.

which underlines the importance of the human factor as a level of product contamination.

\section{CONCLUSION}

The high values of the total germ count (TGC) and some high levels of Escherichia coli have lead to the modification of the packaging technology with a more modern one which limits the human contact and the environment surfaces with the end products. The improvement was obvious given the substantial decrease of the TGC and Escherichia coli compared to the previous values.

The appearance of a contamination case with Salmonella in three batches was due to the contamination through one operator which apparently was healthy. The measures taken have implied the daily instruction of the operators and the signing of a form regarding the health state.

\section{REFERENCES}

1. Mihaiu, Marian (2010). Igiena, calitatea şi tehnologia alimentelor. Vol. 1: Carnea, Risoprint, Cluj-Napoca.

2. Regulamentul (CE) NR. 1441/2007 AL COMISIEI din 5 decembrie 2007 de modificare a Regulamentului (CE) nr. 2073/2005 privind criteriile microbiologice pentru produsele alimentare, Jurnalul Oficial al Uniunii Europene din 7.12.2007 